\title{
Studies of the Mechanism through Which Sodium Depletion Increases Aldosterone Biosynthesis in $\operatorname{Man} *$
}

\author{
Turner Bledsoe, Donald P. Island, and Grant W. Liddle $\dagger$ \\ (From the Department of Medicine, Vanderbilt University School of Medicine, Nashville, Tenn.)
}

Although considerable effort has been directed toward an understanding of the extra-adrenal factors that regulate aldosterone secretion, comparatively little attention has been given to the intraadrenal mechanisms through which these factors effect an increase in aldosterone biosynthesis. It has been established that aldosterone is synthesized by the adrenal cortex by a series of reactions that involve progesterone, deoxycorticosterone, and corticosterone as successive precursors $(1-4)$. It is possible that cholesterol $(4,5)$ is a precursor of progesterone in this pathway and that 18-hydroxycorticosterone is an intermediate between corticosterone and aldosterone $(6,7)$. Since it is known that depletion of body sodium (natropenia) is an effective stimulus to aldosterone secretion $(8,9)$ and excretion $(10)$, this study was undertaken to provide information as to where in this biosynthetic pathway sodium depletion exerts its stimulatory effect.

The idea that the natropenic stimulus to aldosterone secretion is mediated by increases in plasma angiotensin has much to recommend it (11-14), but this concept has not been established to the satisfaction of all investigators (15-17). Therefore, in the present investigation it was considered desirable to make no assumptions as to what the mediator of the natropenic stimulus to aldosterone secretion might be but, rather, to study the intact human organism under conditions of controlled sodium intake. Experiments were designed to determine whether the stimulus of sodium depletion

* Submitted for publication August 13, 1965 ; accepted December 16, 1965.

These studies were supported in part by the following grants-in-aid from the National Institutes of Health of the U. S. Public Health Service: AM-05318, T1-AM5092, 5-K6-AM-3782, and 8-MO1-FR-95.

$\dagger$ Address requests for reprints to Dr. Grant W. Liddle, Dept. of Medicine, Vanderbilt University School of Medicine, Nashville, Tenn. 37203. acts early in the pathway of aldosterone biosynthesis so as to increase the biogenesis of aldosterone precursors or whether it acts late in this pathway, merely to enhance the conversion of corticosterone to aldosterone. It was reasoned that, if natropenia acts early in this pathway so as to increase the adrenal synthesis of aldosterone precursors, then during sodium depletion there might be an increase in precursor secretion as well as an increase in aldosterone secretion.

\section{Methods}

The subjects of this study included six normal volunteers and one patient (C.W.) with hypopituitarism, who was maintained on constant doses of cortisol and thyroid replacement therapy. All subjects were maintained on constant diets analyzed for content of sodium and potassium. Sodium depletion was accomplished through the restriction of sodium intake to less than $15 \mathrm{mEq}$ per day. In most cases triamterene was administered in doses of $100 \mathrm{mg}$ per day on the first 1 to 3 days of sodium restriction. Sodium repletion was accomplished by the rapid intravenous administration of physiologic saline in amounts sufficient to correct the calculated cumulative negative sodium balance, given on the day of resumption of high sodium intake. Daily 24-hour urine samples were collected and analyzed for content of sodium and potassium by flame photometry and for content of creatinine (18).

The secretion rates of corticosterone were determined by a modification of the double isotope dilution derivative technique previously described (19), but utilizing partial hydrolysis of the 3,21-diacetate of tetrahydrocorticosterone with $0.4 \% \mathrm{KHCO}_{3}$ in methanol for 8 hours at room temperature instead of hydrolysis with acetylcholinesterase. Recovery of injected isotope through the hydrolytic procedure ranged from 58 to $84 \%$.

The secretion rate of aldosterone was determined by a double isotope dilution derivative method described previously (19).

The secretion rate of DOC 1 was determined by utiliz-

1 Abbreviations of steroids are as follows: $\mathrm{DOC}=$ deoxycorticosterone; THDOC $=$ pregnane-3 $\alpha, 21$-diol-20one ; $\mathrm{TA}_{\mathrm{c}}=\Delta^{4}$-androstene-17 $\beta$-acetoxy-3-one ; $\mathrm{THE}=$ pregnane- $3 \alpha, 17 \alpha, 21$-triol-11,20-dione ; $\mathrm{THF}=$ pregnane- 
ing the following technique. One $\mu \mathrm{c}$ of $\mathrm{DOC}-4-{ }^{14} \mathrm{C}$ was injected intravenously. Urine was collected for the ensuing 48 or 72 hours, and one-third aliquots of these collections were pooled and taken for analysis. The urine was extracted with 2 vol of dichloromethane, and the organic phase was discarded. The urine was then hydrolyzed with $\beta$-glucuronidase (19) for 24 to 48 hours and extracted with 2 vol of carbon tetrachloride. The organic phase was washed successively with $\frac{1}{10}$ vol of $0.1 \mathrm{~N}$ $\mathrm{NaOH}$, distilled water, and $0.1 \%$ acetic acid, and then dried in vacuo. The extract was purified by paper chromatography in system I for 4 hours (THDOC $R_{\mathfrak{f}}=$ 0.72 ), system II for 4 hours (THDOC $R_{t}=0.58$ ), and system III for 6 hours (THDOC $R_{t}=0.30$ ). See Table I for chromatographic systems. The THDOC was then eluted and desiccated in vacuo for 12 hours. Acetylation with acetic anhydride- ${ }^{8} \mathrm{H}$ (SA approximately $10 \mu \mathrm{c}$ per $\mu$ mole) was carried out as previously described (21). The THDOC diacetate was chromatographed successively in system IV for 16 hours $\left(\operatorname{RTA}_{c}=1.47\right.$ ) and system V for 24 hours $\left(R_{t}=0.11\right)$. The purified 3,21-diacetate of THDOC was then hydrolyzed to the 3-monoacetate by using $0.5 \mathrm{ml}$ of $0.4 \% \mathrm{KHCO}_{3}$ in dry methanol for 8 hours at room temperature. Two $\mathrm{ml}$ of distilled water was added, and the hydrolysis product was extracted into $10 \mathrm{ml}$ of dichloromethane. After evaporation of the solvent, the 3-monoacetate was chromatographed in system $\mathrm{V}$ for 24 hours $\left(\operatorname{RTA}_{c}=0.81\right)$. Recoveries of the monacetate from the diacetate at this point ranged from 41 to $78 \%$. The monoacetate was rechromatographed in system VI for 4 hours $\left(\operatorname{RTA}_{c}=1.13\right)$. Portions of the eluates from the final two systems were counted to check for constancy of specific activity, and the secretion rates were calculated.

The double isotope dilution derivative technique for measurement of cortisol secretion rates was carried out as follows. One $\mu \mathrm{c}$ of cortisol- $-{ }^{14} \mathrm{C}$ was injected intravenously. Urine was collected for 24 hours and a onefifth to one-third aliquot was taken for analysis. The urine was extracted with dichloromethane; the aqueous phase was then hydrolyzed with $\beta$-glucuronidase and extracted with dichloromethane. The dichloromethane was dried, and the residue was redissolved in ethanol. THE and THF were partially purified by chromatography in system VII for 9 hours, as previously described (22). The radioactive areas corresponding to THE and THF were then eluted and acetylated with acetic anhydride- ${ }^{3} \mathrm{H}$ (10 $\mu \mathrm{c}$ per $\mu$ mole). The THE $A_{c_{2}}$ and THF $A_{c_{2}}$ were then chromatographed successively in system VIII for 9 hours ( $T H F A_{c_{2}} R_{\text {DoCA }}=0.84$, and THE $A_{c_{2}} R_{\text {DocA }}=$ 0.83 ) and system III for 6 hours (THE $A_{\mathrm{c}_{2}} \mathrm{R}_{\mathrm{DOCA}}=$ 0.80 , and THF $\left.A_{c_{2}} R_{\text {Docs }}=0.55\right)$. The purified diacetates of THE and THF were dissolved in $0.45 \mathrm{ml}$ methanol and cooled to $0^{\circ} \mathrm{C}$; then $0.05 \mathrm{ml}$ of $3 \mathrm{M} \mathrm{KBH}_{4}$ in distilled water was added. After 5 minutes at $0^{\circ} \mathrm{C}$, the

$3 \alpha, 11 \beta, 17 \alpha, 21$-tetrol-20-one ; THE $\mathrm{A}_{\mathrm{c}_{2}}=$ pregnane-3 $\alpha, 21$ diacetoxy-17 $\alpha$-ol-11,20-dione; $\mathrm{THF} \mathrm{A}_{\mathrm{e} 2}=$ pregnane- $3 \alpha, 21$ diacetoxy-11 $\beta, 17 \alpha$-diol-20-one ; and DOCA $=\Delta^{4}$-pregnene21-acetoxy-3,20-dione.
TABLE I

Paper chromatographic systems

\begin{tabular}{|c|c|}
\hline System & \\
\hline I & $\begin{array}{l}\text { Cyclohexane: benzene: : methanol: water } \\
5: 10:: 10: 2,30^{\circ} \mathrm{C}\end{array}$ \\
\hline II & $\begin{array}{l}\text { Isooctane : } t \text {-butanol: : methanol: water } \\
180: 75:: 45: 30,30^{\circ} \mathrm{C}\end{array}$ \\
\hline III & $\begin{array}{l}\text { Cyclohexane: benzene: : methanol: water } \\
10: 2: 5:: 10: 1,30^{\circ} \mathrm{C}\end{array}$ \\
\hline IV & Cyclohexane:phenylcellosolve, $25^{\circ} \mathrm{C}$ \\
\hline V & Methanol: water $2: 1:$ : mesitylene, $25^{\circ} \mathrm{C} *$ \\
\hline VI & $\begin{array}{l}\text { Cyclohexane: : nitromethane: methanol } \\
6:: 1: 1,25^{\circ} \mathrm{C}\end{array}$ \\
\hline VII & Benzene: : methanol: water $4:: 2: 1,30^{\circ} \mathrm{C}$ \\
\hline VIII & $\begin{array}{l}\text { Cyclohexane: dioxane: : methanol: water } \\
10: 5:: 10: 1,25^{\circ} \mathrm{C}\end{array}$ \\
\hline IX & Heptane: : methanol: water $4:: 3: 1,30^{\circ} \mathrm{C}$ \\
\hline $\mathbf{X}$ & $\begin{array}{l}\text { Cyclohexane: benzene: : methanol: nitromethane } \\
4: 1:: 1: 1,25^{\circ} \mathrm{C}\end{array}$ \\
\hline $\mathbf{X I}$ & Methanol: water $4: 1:$ : mesitylene, $30^{\circ} \mathrm{C}$ \\
\hline
\end{tabular}

* Used as a reverse-phase system (20).

reaction was terminated by addition of $0.1 \mathrm{ml}$ of $10 \% \mathrm{HCl}$ and $2 \mathrm{ml}$ of distilled water, and $\mathrm{pH}$ was rapidly adjusted to the range of 4 to 6 . The reduction products were then extracted into $15 \mathrm{ml}$ of dichloromethane, and the organic phase was washed twice with $2 \mathrm{ml}$ of distilled water and dried. To the reduction products $1 \mathrm{ml}$ of methanol and $1 \mathrm{ml}$ of $0.1 \mathrm{M}$ periodic acid in $2 \%$ pyridine were then added, and the mixture was allowed to stand at $25^{\circ} \mathrm{C}$ for 8 to 12 hours. Three $\mathrm{ml}$ of distilled water was added, and the 3-acetoxy derivates of etiocholane-11,17 -dione and etiocholane-11 $\beta_{0}$ l-17-one were extracted into $50 \mathrm{ml}$ of dichloromethane, washed twice with $\frac{1}{10}$ vol of distilled water, and dried. Recovery of 3-acetoxy-etiocholane-11,17-dione from THE $A_{c_{2}}$ ranged from 67 to $81 \%$. Recovery of 3-acetyoxy-etiocholane-11 $\beta$ ol-17-one from THF $\mathrm{A}_{c_{2}}$ ranged from 33 to $69 \%$. The 3-acetoxy-etiocholane-11,17-dione was chromatographed successively in system XI for 24 hours $\left(\operatorname{RTA}_{c}=1.22\right)$ and system $X$ for 4 hours $\left(\operatorname{RTA}_{c}=0.79\right)$. The 3 -acetoxy-etiocholane-11 $\beta$ ol-17-one was chromatographed successively in system IX for 4 hours $\left(R_{D O C A}=1.0\right.$, and $R_{f}=0.38$ ) and system $X$ for 4 hours $\left(R_{T A_{c}}=1.12\right)$. Portions of the eluates of the final two systems were counted and the secretion rates calculated as before. In this study, secretion rates as calculated from specific activities of THE and THF were in close agreement.

\section{Results}

Elimination of ACTH-dependent secretion of corticosterone. Early in the study it was recognized that much of the corticosterone that is produced by the human adrenal is secreted under the influence of adrenocorticotropic hormone and might be formed in cells that are not involved in the biosynthesis of aldosterone. If the magnitude of ACTH-dependent production of corticosterone 


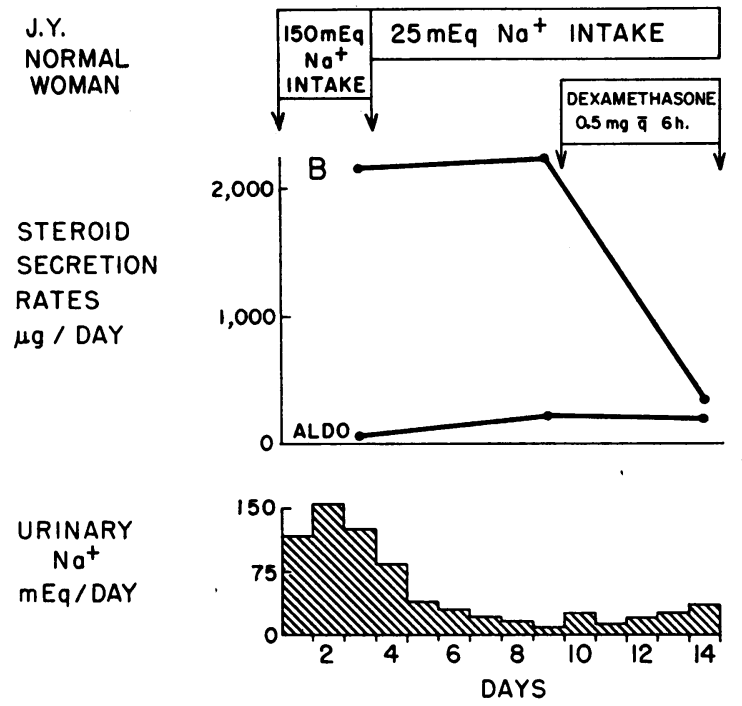

Fig. 1. THE EFFECTS OF DIETARY SODIUM RESTRICTION AND OF DEXAMETHASONE UPON THE CORTICOSTERONE (B) AND ALDOSTERONE (ALDO) SECRETION RATES OF A NORMAL SUBJECT.

were large compared with that of the aldosteronerelated production of corticosterone, it seemed possible that changes in corticosterone secretion rate induced by natropenia might be obscured. The effect of eliminating ACTH-dependent secretion of corticosterone is illustrated in Figure 1. A nor- mal subject maintained on high sodium intake secreted $54 \mu \mathrm{g}$ of aldosterone and 2,200 $\mu \mathrm{g}$ of corticosterone per day. Maintenance on low sodium intake for several days resulted in a rise in aldosterone secretion rate to $220 \mu \mathrm{g}$ per day without a distinct change in corticosterone secretion rate. Dexamethasone was administered in doses of 0.5 mg every 6 hours to eliminate ACTH-dependent secretion of corticosterone. In response to dexamethasone, corticosterone secretion rate fell to less than $400 \mu \mathrm{g}$ per day, whereas the aldosterone secretion rate was not appreciably affected. Two additional studies also provided evidence that, in normal subjects on liberal sodium intake, approximately $90 \%$ of the corticosterone is ACTH dependent. In all subsequent experiments, therefore, the ACTH-dependent secretion of corticosterone was eliminated by the continuous administration of dexamethasone throughout the study.

Effect of sodium depletion on aldosterone, corticosterone, and cortisol secretion rates of normal subjects receiving dexamethasone (Table II). With ACTH-dependent secretion of corticosterone eliminated by the administration of dexamethasone, it became relatively simple to demonstrate an effect of sodium depletion on corticosterone secretion. In three normal subjects aldosterone, corticosterone, and cortisol secretion rates were

TABLE II

Effects of sodium depletion on steroid secretion rates of normal subjects receiving dexamethasone, $0.75 \mathrm{mg}$, every 8 hours

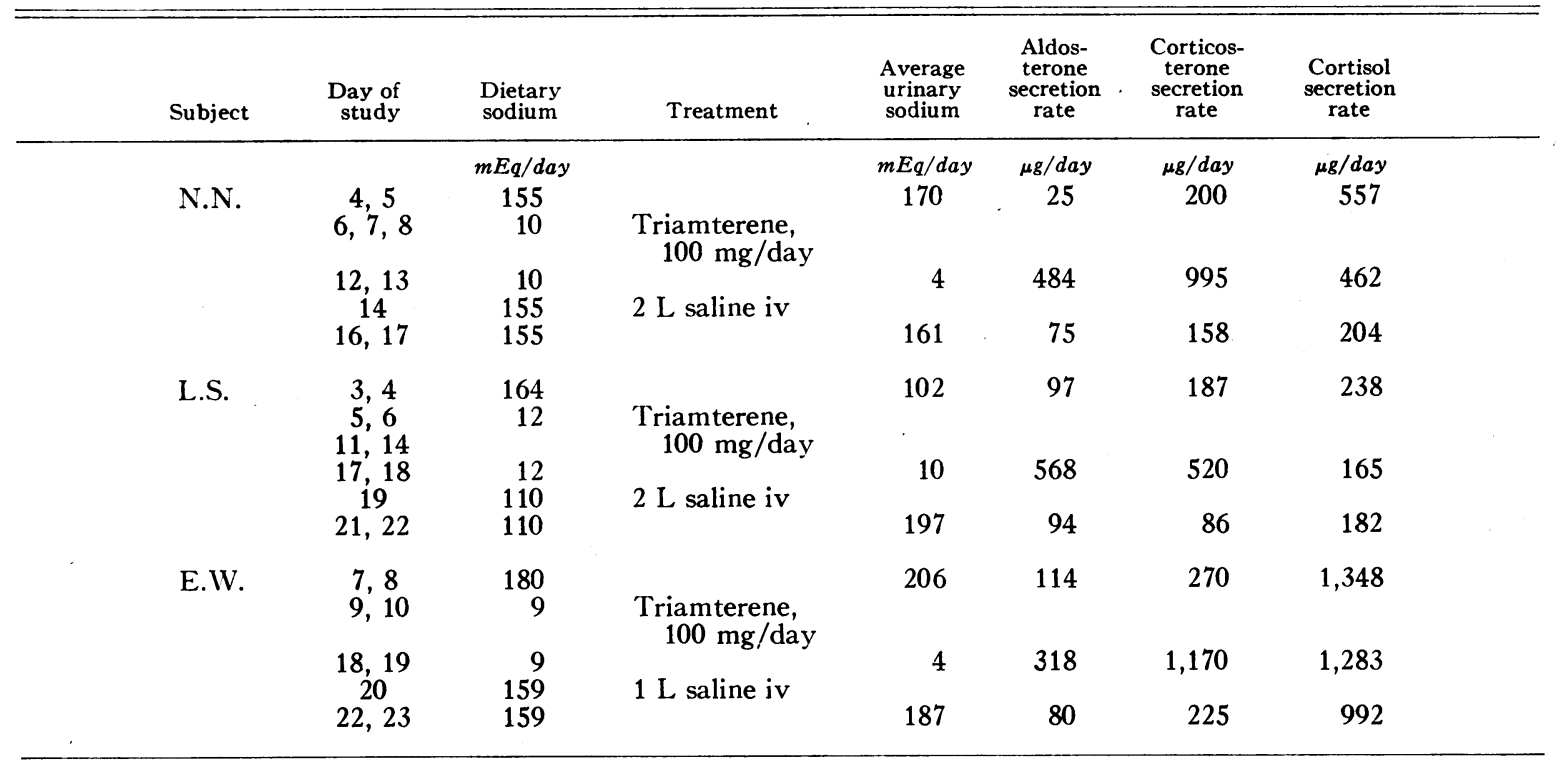


determined while they were receiving high sodium diets, after they had been maintained for several days on low sodium diets, and a third time after they had resumed high sodium diets and received intravenous infusions of physiologic saline in quantities sufficient to correct sodium depletion. In all three subjects, sodium depletion induced increases in corticosterone as well as aldosterone secretion rates, but cortisol secretion rates were not affected.

Effect of sodium depletion on deoxycorticosterone secretion in normal subjects receiving dexamethasone and Metopirone (Table III). To evaluate the effect of sodium depletion on aldosterone synthesis at an earlier stage in the biosynthetic sequence, deoxycorticosterone secretion rates were measured before, during, and after a period of sodium deprivation in three normal subjects and one patient with hypopituitarism. Although deoxycorticosterone is an important intermediate in the biosynthesis of corticosterone and aldosterone and must, therefore, be produced by the adrenal in fairly large quantities, little is actually secreted into the bloodstream. To employ deoxycorticosterone secretion rate as an index of intra-adrenal formation of deoxycorticosterone, we employed constant doses of Metopirone. This 11 $\beta$-hydroxylase inhibitor impairs the conversion of deoxycorticosterone to corticosterone with a consequent increase in the secretion of deoxycorticosterone (23). As in previous experiments, constant doses of dexamethasone were employed to reduce the formation of ACTH-dependent steroids to a minimum. It is to be emphasized that both Metopirone and dexamethasone were given constantly throughout this study and that the only experimental variable was the sodium intake. During the initial "high sodium" period, deoxycorticosterone secretion rates were relatively low, but in all four experiments they rose in response to sodium deprivation. After resumption of high sodium intake, all four subjects experienced decreases in deoxycorticosterone secretion rates.

Comparative effects of sodium depletion and ACTH on cortisol, corticosterone, and aldosterone secretion of normal subjects receiving dexamethasone. Large doses of ACTH have previously been shown to have a transient stimulatory effect on aldosterone output (24). Whether physiologic

TABLE III

Effects of sodium depletion on deoxycorticosterone secretion rates in subjects receiving 500 mg Metopirone every 4 hours and $0.375 \mathrm{mg}$ dexamethasone every 4 hours

\begin{tabular}{|c|c|c|c|c|c|c|}
\hline Subject & Day of study & $\begin{array}{l}\text { Dietary } \\
\text { sodium }\end{array}$ & Treatment & $\begin{array}{l}\text { Average } \\
\text { urinary } \\
\text { sodium }\end{array}$ & $\begin{array}{l}\text { Deoxycorti- } \\
\text { costerone } \\
\text { secretion } \\
\text { rate }\end{array}$ & $\begin{array}{l}\operatorname{cpm}{ }^{3} \mathrm{H} /{ }^{14} \mathrm{C} \\
\text { of final } \\
\text { samples }\end{array}$ \\
\hline \multirow{5}{*}{ L.S. } & & $m E q / d a y$ & \multirow{3}{*}{$\begin{array}{l}\text { Triamterene, } \\
100 \mathrm{mg} / \text { day }\end{array}$} & $m E q / d a y$ & $\mu g / d a y$ & \\
\hline & 2,63 & $\begin{array}{c}164 \\
12\end{array}$ & & 211 & 573 & $4,691 / 362$ \\
\hline & \multirow{3}{*}{$\begin{array}{l}11,12 \\
14 \\
16,17\end{array}$} & \multirow{3}{*}{$\begin{array}{r}12 \\
164 \\
164\end{array}$} & & 30 & 1,836 & $1.659 / 40$ \\
\hline & & & \multirow[t]{2}{*}{$2 \mathrm{~L}$ saline iv } & & & \\
\hline & & & & 186 & 744 & $4,960 / 421$ \\
\hline \multirow[t]{3}{*}{ M.S. } & 9,10 & 166 & \multirow{3}{*}{$1 \mathrm{~L}$ saline iv } & 185 & 132 & $630 / 275$ \\
\hline & 13,14 & 8 & & 12 & 320 & $4,216 / 767$ \\
\hline & 17,18 & $\begin{array}{l}100 \\
166\end{array}$ & & 155 & 159 & $2,434 / 596$ \\
\hline \multirow[t]{4}{*}{ E.W. } & $9,10,11$ & 88 & \multirow{3}{*}{$\begin{array}{l}\text { Triamterene, } \\
100 \mathrm{mg} / \text { day }\end{array}$} & 162 & 234 & $.758 / 100$ \\
\hline & $12,13,14$ & 14 & & & & \\
\hline & $17,18,19$ & \multirow{2}{*}{$\begin{array}{l}14 \\
88\end{array}$} & & 13 & 650 & $17,041 / 809$ \\
\hline & $23,24,25$ & & $2 \mathrm{~L}$ saline iv & 151 & 166 & $2,651 / 491$ \\
\hline \multirow{4}{*}{$\begin{array}{l}\text { C.W. } \\
\text { (Hypopituitarism) }\end{array}$} & $11,12,13$ & 170 & & 164 & 279 & $207 / 28$ \\
\hline & 14,15 & 11 & \multirow[t]{3}{*}{$\begin{array}{l}\text { Triamterene, } \\
100 \mathrm{mg} / \text { day }\end{array}$} & & & \\
\hline & $\begin{array}{c}17,18,19 \\
20,21,22,23\end{array}$ & $\begin{array}{r}11 \\
170\end{array}$ & & 13 & 472 & $488 / 39$ \\
\hline & $24,25,26$ & 170 & & 153 & 148 & $55 / 14$ \\
\hline
\end{tabular}


TABLE IV

Effects of small doses of ACTH on steroid secretion rates in normal subjects maintained on constant high sodium intake and receiving $0.75 \mathrm{mg}$ dexamethasone every 8 hours

\begin{tabular}{|c|c|c|c|c|}
\hline Subject & Treatment period & $\begin{array}{l}\text { Aldosterone } \\
\text { secretion rate }\end{array}$ & $\begin{array}{l}\text { Corticosterone } \\
\text { secretion rate }\end{array}$ & $\begin{array}{c}\text { Cortisol } \\
\text { secretion rate }\end{array}$ \\
\hline L.B. & $\begin{array}{l}\text { Control } \\
\text { ACTH, } 0.06 \mathrm{U} / \text { hour } \\
\text { Postinfusion }\end{array}$ & $\begin{array}{c}\mu g / d a y \\
14 \\
14 \\
26\end{array}$ & $\begin{array}{c}\mu g / d a y \\
200 \\
458 \\
182\end{array}$ & $\begin{array}{r}\mu g / d a y \\
1,098 \\
3,515 \\
821\end{array}$ \\
\hline J.S. & $\begin{array}{l}\text { Control } \\
\text { ACTH, } 0.08 \mathrm{U} / \text { hour }\end{array}$ & $\begin{array}{l}63 \\
66\end{array}$ & $\begin{array}{l}179 \\
661\end{array}$ & $\begin{array}{r}951 \\
3,948\end{array}$ \\
\hline R.W. & $\begin{array}{l}\text { Control } \\
\text { ACTH, } 0.07 \mathrm{U} / \text { hour }\end{array}$ & $\begin{array}{l}115 \\
142\end{array}$ & $\begin{array}{l}417 \\
710\end{array}$ & $\begin{array}{l}1,112 \\
3,158\end{array}$ \\
\hline
\end{tabular}

levels of ACTH have measurable effects on aldosterone, however, has never been clearly demonstrated. It was considered important to exclude the possibility that the effects of sodium depletion on aldosterone, corticosterone, and deoxycorticosterone secretion might be mediated by small amounts of ACTH. An experiment was designed, therefore, to compare the effects of small doses of ACTH with those of sodium depletion upon steroid secretion patterns. The effects of sodium depletion have already been recorded in Table II. The effects of ACTH are shown in Table IV. Three normal subjects, maintained on constant doses of dexamethasone and constant high sodium diets, underwent steroid secretion rate determinations during control periods and while receiving ACTH by constant intravenous infusion in the small doses of "0.06 to 0.08 " U per hour for 24 hours. Under these conditions, ACTH induced distinct increases in cortisol secretion without appreciably affecting aldosterone secretion. In contrast, sodium deprivation induced distinct increases in aldosterone secretion without appreciably affecting cortisol secretion. Both ACTH and sodium deprivation were effective stimuli to corticosterone secretion.

\section{Discussion}

Although it has been known for many years that sodium depletion stimulates the secretion of aldosterone by the human adrenal cortex, it has never been clearly demonstrated whether the point at which this stimulation occurs is early in the biosynthetic pathway (to increase the availability of aldosterone precursors), late in the biosynthetic pathway (to enhance the conversion of corticosterone to aldosterone), or perhaps at both of these points. Ulick, Nicolis, and Vetter have shown that sodium depletion results in an increase in secretion of 18-hydroxycorticosterone. Whether this steroid should be regarded as the immediate precursor to aldosterone or as a side-product in aldosterone biosynthesis is not yet clear (6). In the present investigation we have demonstrated that, under appropriate conditions, sodium depletion consistently increases the secretion of corticosterone and deoxycorticosterone. It is apparent, therefore, that the effect of sodium depletion is not limited to stimulation of the final step in aldosterone biosynthesis; it acts at some early step in the biosynthetic pathway, before the formation of deoxycorticosterone, to increase the availability of aldosterone precursors.

Further evidence that natropenia leads to increased formation of aldosterone precursors is derived from observations of patients with isolated inborn errors of aldosterone biosynthesis. Visser and Cost (25) and Ulick and associates (26) have studied patients with isolated defects in adrenocortical 18-oxidation, aldosterone deficiency, and sodium depletion. Both found evidence of increased corticosterone secretion. In the case described by Ulick, sodium loading produced a significant fall in the corticosterone secretion rate. One case described by Visser was also found to have increased deoxycorticosterone secretion. These observations suggest that the effects we have demonstrated are not peculiar to the adrenal suppressed with dexamethasone. Although dexamethasone and Metopirone seemed to be technologically useful in bringing to light the effects of natropenia on corticosterone and deoxycorticos- 
terone secretion, there is no reason to believe that the effects could not be demonstrated (albeit with greater difficulty) in the absence of these agents.

The present study does not explain how natropenia increases the availability of aldosterone precursors. Nor does it entirely exclude the possibility that natropenia might, in addition to increasing the availability of precursors, have some effect on the conversion of corticosterone to aldosterone.

It has been suggested that angiotensin might be the mediator of the natropenic stimulus to aldosterone secretion $(11,12,14)$, and it has been observed that angiotensin acts early in the aldosterone biosynthetic pathway (5). In designing the present study we preferred to make no assumptions as to whether angiotensin is the mediator of the natropenic stimulus to aldosterone secretion. The results of the present investigation indicate that natropenic stimulation of the aldosterone biosynthetic pathway is relatively specific in the sense that no stimulation of cortisol secretion was observed. Any agent that is postulated to be the mediator of the natropenic stimulus to aldosterone secretion must be similarly specific in its action. $\mathrm{Up}$ to the present time there has been disagreement as to whether angiotensin does or does not act to stimulate aldosterone secretion without simultaneously stimulating cortisol secretion (27-30).

It is possible that aldosterone and cortisol are synthesized by different cells. If so, the aldosterone-secreting cells appear to be responsive to sodium depletion but not to small doses of ACTH, and the cortisol-secreting cells appear to be responsive to ACTH but not to sodium depletion. Both types of cells respond to their respective stimulating agents with increased secretion of corticosterone. This view would fit well with the following observations of the present study: 1) small doses of ACTH increase corticosterone secretion without affecting aldosterone secretion; 2) dexamethasone suppresses corticosterone secretion without affecting aldosterone secretion; and 3) sodium depletion, while not affecting cortisol secretion, does stimulate the production of aldosterone precursors.

Since corticosterone production is under dual control, being secreted both in response to ACTH and sodium depletion, corticosterone measurements cannot be substituted for measurements of cortisol in determining whether the action of a particular stimulus is limited to the aldosterone pathway. For example, a rise in cortisol in response to angiotensin would constitute evidence that angiotensin was not a specific stimulus of the aldosterone pathway, but a rise in corticosterone would not.

\section{Summary}

Experiments were designed to determine whether sodium depletion stimulates the conversion of corticosterone to aldosterone or whether it stimulates the biogenesis of aldosterone precursors. Steroid secretion rates were measured by double isotope dilution derivative methods. To eliminate ACTH-dependent steroid synthesis, the crucial experiments were performed in subjects receiving constant dosage of dexamethasone. Under these conditions sodium depletion caused consistent increases in aldosterone and corticosterone secretion rates without appreciably affecting the cortisol secretion rate. The effect of sodium depletion on the adrenal secretion of deoxycorticosterone was measured during continuous administration of both dexamethasone and Metopirone. In subjects receiving dexamethasone, Metopirone, and a low sodium diet, deoxycorticosterone secretion rates were consistently higher than when the same subjects received dexamethasone, Metopirone, and a high sodium diet. It is concluded that sodium depletion stimulates the aldosterone biosynthetic pathway at some step before the formation of deoxycorticosterone so as to increase the availability of aldosterone precursors. This action is relatively specific for the aldosterone pathway and does not appreciably affect the secretion of cortisol. In contrast, small doses of ACTH were shown to stimulate the secretion of cortisol and corticosterone without appreciably affecting the secretion of aldosterone.

\section{References}

1. Ayres, P. J., O. Hechter, N. Saba, S. A. Simpson, and J. F. Tait. Intermediates in the biosynthesis of aldosterone by capsule strippings of ox adrenal gland. Biochem. J. 1957, 65, 22 p.

2. Giroud, C. J. P., J. Stachenko, and P. Piletta. In vitro studies of the functional zonation of the adrenal cortex and of the production of aldosterone in Aldosterone, A. F. Muller and C. M. O'Connor, Eds. Boston, Little, Brown, 1958, p. 56. 
3. Travis, R. H., and G. L. Farrell. In vitro biosynthesis of isotopic aldosterone: comparison of precursors. Endocrinology 1958, 63, 882.

4. Ayres, P. J., J. Eichhorn, O. Hechter, N. Saba, J. F. Tait, and S. A. S. Tait. Some studies on the biosynthesis of aldosterone and other adrenal steroids. Acta Endocr. (Kbh.) 1960, 33, 27.

5. Kaplan, N. M., and F. C. Bartter. The effect of $\mathrm{ACTH}$, renin, angiotensin II, and various precursors on biosynthesis of aldosterone by adrenal slices. J. clin. Invest. 1962, 41, 715.

6. Ulick, S., G. S. Nicolis, and K. K. Vetter. Relationship of 18-hydroxycorticosterone to aldosterone in Aldosterone, E. E. Baulieu and P. Robel, Eds. Philadelphia, F. A. Davis, 1964, p. 3.

7. Pasqualini, J. R. Conversion of tritiated-18-hydroxycorticosterone to aldosterone by slices of human cortico-adrenal gland and adrenal tumour. $\mathrm{Na}$ ture (Lond.) 1964, 201, 501.

8. Ulick, S., J. H. Laragh, and S. Lieberman. The isolation of a urinary metabolite of aldosterone and its use to measure the rate of secretion of aldosterone by the adrenal cortex of man. Trans. Ass. Amer. Phycns 1958, 71, 225.

9. Ayres, P. J., J. Barlow, O. Garrod, A. E. Kellie, S. A. S. Tait, J. F. Tait, and G. Walker. The metabolism of $\left[16-{ }^{3} \mathrm{H}\right]$ aldosterone in man in An International Symposium on Aldosterone, A. F. Muller and C. M. O'Connor, Eds. Boston, Little, Brown, 1958, p. 73.

10. Luetscher, J. A., Jr., and B. J. Axelrad. Increased aldosterone output during sodium deprivation in normal men. Proc. Soc. exp. Biol. (N. Y.) 1954 , 87, 650 .

11. Davis, J. O., C. C. J. Carpenter, C. R. Ayers, J. E. Holman, and R. C. Bahn. Evidence for secretion of an aldosterone-stimulating hormone by the kidney. J. clin. Invest. 1961, 40, 684.

12. Genest, J. Angiotensin, aldosterone and human arterial hypertension. Canad. med. Ass. J. 1961, 84, 403.

13. Laragh, J. H., M. Angers, W. G. Kelly, and S. Lieberman. Hypotensive agents and pressor substances. J. Amer. med. Ass. 1960, 174, 234.

14. Carpenter, C. C. J., J. O. Davis, and C. R. Ayers. Relation of renin, angiotensin II, and experimental renal hypertension to aldosterone secretion. J. clin. Invest. 1961, 40, 2026.

15. Mulrow, P. J., and W. F. Ganong. The role of the renin-angiotensin system in the regulation of aldosterone secretion in the dog and man in Aldosterone, E. E. Baulieu and P. Robel, Eds. Philadelphia, F. A. Davis, 1964, p. 265.

16. Blair-West, J. R., G. W. Boyd, J. P. Coghlan, D. A. Denton, J. R. Goding, M. Wintour, and R. D. Wright. Experimental observations on aldosterone secretion in sheep in Aldosterone, E. E. Baulieu and P. Robel, Eds. Philadelphia, F. A. Davis, 1964, p. 203.
17. Eilers, E. A., and R. E. Peterson. Aldosterone secretion in the rat in Aldosterone, E. E. Baulieu and P. Robel, Eds. Philadelphia, F. A. Davis, 1964, p. 251.

18. Hawk, P. B., B. L. Oser, and W. H. Summerson. Practical Physiological Chemistry, 13th ed. New York, Blakiston, 1954, p. 899.

19. Bledsoe, T., D. P. Island, A. M. Riondel, and G. W. Liddle. Modification of aldosterone secretion and electrolyte excretion in man by a chemical inhibitor of 18-oxidation. J. clin. Endocr. 1964, 24, 740.

20. Peterson, R. E. Determination of peripheral plasma aldosterone in Aldosterone, E. E. Baulieu and P. Robel, Eds. Philadelphia, F. A. Davis, 1964, p. 145.

21. Kliman, B., and R. E. Peterson. Double isotope derivative assay of aldosterone in biological extracts. J. biol. Chem. 1960, 235, 1639.

22. Ney, R. L., W. S. Coppage, Jr., N. Shimizu, D. P. Island, C. F. Zukoski, and G. W. Liddle. Effects of triparanol on the secretion and metabolism of adrenal corticosteroids. J. clin. Endocr. 1962, 22, 1057.

23. Liddle, G. W., D. Island, E. M. Lance, and A. P. Harris. Alterations of adrenal steroid patterns in man resulting from treatment with a chemical inhibitor of $11 \beta$-hydroxylation. J. clin. Endocr. 1958, 18, 906.

24. Liddle, G. W., L. E. Duncan, Jr., and F. C. Bartter. Dual mechanism regulating adrenocortical function in man. Amer. J. Med. 1956, 21, 380.

25. Visser, H. K. A., and W. S. Cost. A new hereditary defect in the biosynthesis of aldosterone: urinary $\mathrm{C}_{21}$-corticosteroid pattern in three related patients with a salt-losing syndrome, suggesting an 18-oxidation defect. Acta Endocr. (Kbh.) 1964, 47, 589.

26. Ulick, S., E. Gautier, K. K. Vetter, J. R. Markello, S. Yaffe, and C. U. Lowe. An aldosterone biosynthetic defect in a salt-losing disorder. J. clin. Endocr. 1964, 24, 669.

27. Biron, P., E. Koiw, W. Nowaczynski, J. Brouillet, and J. Genest. The effects of intravenous infusions of valine-5 angiotensin II and other pressor agents on urinary electrolytes and corticosteroids, including aldosterone. J. clin. Invest. 1961, 40, 338.

28. Ames, R. P., A. J. Borkowski, A. M. Sicinski, and J. H. Laragh. Prolonged infusions of angiotensin II and norepinephrine and blood pressure, electrolyte balance, and aldosterone and cortisol secretion in normal man and in cirrhosis with ascites. J. clin. Invest. 1965, 44, 1171.

29. Mulrow, P. J., W. F. Ganong, G. Cera, and A. Kuljian. The nature of the aldosterone-stimulating factor in dog kidneys. J. clin. Invest. 1962, 41, 505.

30. Slater, J. D. H., B. H. Barbour, H. H. Henderson, A. G. T. Casper, and F. C. Bartter. Influence of the pituitary and the renin-angiotensin system on the secretion of aldosterone, cortisol, and corticosterone. J. clin. Invest. 1963, 42, 1504. 